\title{
Drought and grazing: II. Effects on runoff and water quality
}

\author{
WILLIAM E. EMMERICH AND R. K. HEITSCHMIDT
}

\begin{abstract}
Authors are Soil Scientist, USDA Agricultural Research Service, Southwest Watershed Research Center, 2000 E. Allen Rd., Tucson, Ariz. 85719 and Supervisory Rangeland Scientist USDA Agricultural Research Service, Fort Keogh Livestock and Range Research Laboratory, Miles City, Mont. 59301.
\end{abstract}

Abstract

Understanding the interacting effects of drought and grazing on runoff, erosion, and nutrient transport is essential for improved rangeland management. Research was conducted at the Fort Keogh Livestock and Range Research Laboratory located near Miles City, Mont. using 12, non-weighing lysimeters for 3 years. During years 1 and 3, no drought treatment was imposed. For year 2, one half of the lysimeters were covered to implement a drought treatment. The 3 grazing treatments were ungrazed, grazed during but not after drought, and grazed during and after drought. Runoff, sediment yield, and an array of nutrients in the runoff water were measured from the lysimeters. First year base line data with no grazing or drought treatments applied indicated no significant differences among lysimeters. Below normal precipitation occurred during year 2 , resulting in no runoff from the drought treatment and negated the "nondrought" control. This prevented a direct assessment of the interaction among the drought and grazing treatments for this year. The drought treatment did produce significant reductions in water, sediment, and nutrient yield. No grazing impact was observed during year 2 . The third year with more normal precipitation, there was a trend toward increased runoff, sediment, and nutrient yield from the second year drought treatment lysimeters. In the third year, both grazing treatments showed significantly greater runoff, sediment, and nutrient yield than the ungrazed treatment. Runoff and sediment yield tended to increase from the combination of drought and grazing treatments. The observed increases in runoff and sediment and reduced water quality from the drought and grazing treatments were measured against controls and when compared to the natural variability and water quality standards, they were concluded to be minimal.

Key Words: erosion, sediment yield, nutrient transport, great plains

Many factors, such as grazing, topography, and type and intensity of precipitation, influence amounts of runoff, erosion, and nutrient transport from rangelands. Excessive runoff, erosion, and nutrient transport degrades water quality, production capacity, and ranch profitability. Of serious concern is the potential for

Authors thank Dr. Gary Richardson for assistance in statistical analysis, and Cheryl Murphy and Charmaine Verdugo for field and laboratory assistance. This research was conducted under a cooperative agreement between USDA-ARS and the Montana Agric. Exp. Sta. Mention of a proprietary product does not constitute a guarantee or warranty of the product by USDA, Montana Agric. Exp. Sta., or the authors and does not imply its approval to the exclusion of other products that may also be suitable. USDA Agricultural Research Service, Northern Plains Area, is an equal opportunity/affirmative action employer and all agency services are available without discrimination.

Manuscript accepted 2 Sept. 01.

\section{Resumen}

Entender los efectos al interactuar la sequía y el apacentamiento en el escurrimiento, erosión y transporte de nutrientes es esencial para un mejor manejo de pastizales. La investigación se condujo en el laboratorio de Investigación en Pastizales y Ganado Fort Keogh localizado cerca de Miles, Montana, tuvo una duración de 3 años y se utilizan 12 lisímetros que no se pesan. Durante los años 1 y 3 no se impusieron tratamientos de sequía, en el año 2, una mitad de los lisímetros se cubrieron para implementar el tratamiento de sequía. Los 3 tratamientos de apacentamiento fueron: sin apacentamiento, apacentamiento durante, pero no después, de la sequía y apacentamiento durante y después de la sequía. De los lisímetros se midió el escurrimiento, la producción de sedimento y el arrastre de nutrientes en el agua del escurrimiento. El primer año, los datos iniciales de los tratamientos sin apacentamiento o sequía no indicaron diferencias significativas entre lisímetros. En el año 2 la precipitación que ocurrió fue abajo de lo normal, lo que resulto en que no hubiera escurrimiento en los tratamientos con sequía y se anulara el tratamiento control de no-sequía; esto evito que ese año se realizara la evaluación directa de la interacción entre los tratamientos de sequía y apacentamiento. El tratamiento de sequía produjo reducciones significativas en la producción de agua, sedimento y nutrientes. El impacto de no apacentar se observó durante el año 2. En el tercer año, en el que se presentó una precipitación arriba de lo normal, hubo una tendencia a incrementar el escurrimiento y la producción de sedimento y nutrientes en los lisímetros del tratamiento del segundo año de sequía. En el tercer año ambos tratamientos de apacentamiento mostraron un escurrimiento y una producción de sedimentos y nutrientes significativamente mayor que el tratamiento sin apacentamiento. El rendimiento de sedimento y el escurrimiento tendió a incrementarse en los tratamientos de la combinación de sequía y apacentamiento. Los incrementos observados en el escurrimiento y sedimento y la reducida calidad del agua de los tratamientos de sequía y apacentamiento se compararon contra los controles, y cuando se compararon con la variabilidad natural y los estándares de calidad de agua, se concluyó que son mínimos.

heavy grazing and drought to interact and accelerate runoff, erosion, and nutrient transport. Such knowledge is critical for developing management strategies to maintain and/or improve rangeland health.

The effects of grazing on runoff, erosion, and nutrient transport have been examined by many (Gifford and Hawkins 1978, McGinty et al. 1979, Robbins 1979, Wood and Blackburn 1981, Jawson et al. 1982, Schepers and Francis 1982). As grazing intensity increases, water quality decreases and nutrient transport increases (Wood and Blackburn 1981, Schepers et al. 1982). 
Sometimes the response is not linear and frequently there is a critical point where dramatic changes occur (Thurow 1991). The response arises from the direct impacts that grazing animals have on rangeland resources; those being increased concentrations of pollutants via deposition of animal wastes, decreased vegetation cover and aboveground plant biomass via consumption and trampling, and increased soil bulk density from trampling of the soil surface (Robbins 1979, Dadkhah and Gifford 1980, Wood and Blackburn 1981). The amount of bare soil surface is linked closely to runoff and erosion amounts (Hofmann et al. 1983) because raindrop impact alters soil structure and reduces aggregate stability directly, which in turn increases runoff and erosion (Thurow et al. 1986). Trampling also reduces water infiltration rates by destroying desired soil structure and increasing bulk density (Hanson et al. 1970, McGinty et al. 1979, Dadkhah and Gifford 1980, Warren et al. 1986b).

Drought can be defined in many different ways (Thurow and Taylor 1999). The Society for Range Management Glossary (Kothmann 1974) uses the meteorologicalbased definition of "prolonged dry weather, generally when precipitation is less than three-quarters of the average annual amount". A detrimental effect of drought on infiltration and erosion can occur under intensive rotational grazing (Warren et al. 1986a). This effect was related to reductions in vegetation cover and aboveground plant biomass. In another study, drought caused the greatest changes in erosion and nutrient transport even when compared to where fire had removed all vegetation (White and Loftin 2000). Our hypothesis was that drought and grazing together would substantially increase runoff, erosion, and nutrient transport during storms that occurred after drought compared to non-drought conditions. The objective of this study was to evaluate the interaction effects of drought and grazing sequences on runoff, erosion, and nutrient transport in a northern Great Plains rangeland setting.

\section{Materials and Methods}

\section{Study Area}

Research was conducted during the 1993-1995 growing seasons at the 22,000 ha, Fort Keogh Livestock and Range Research Laboratory located near Miles

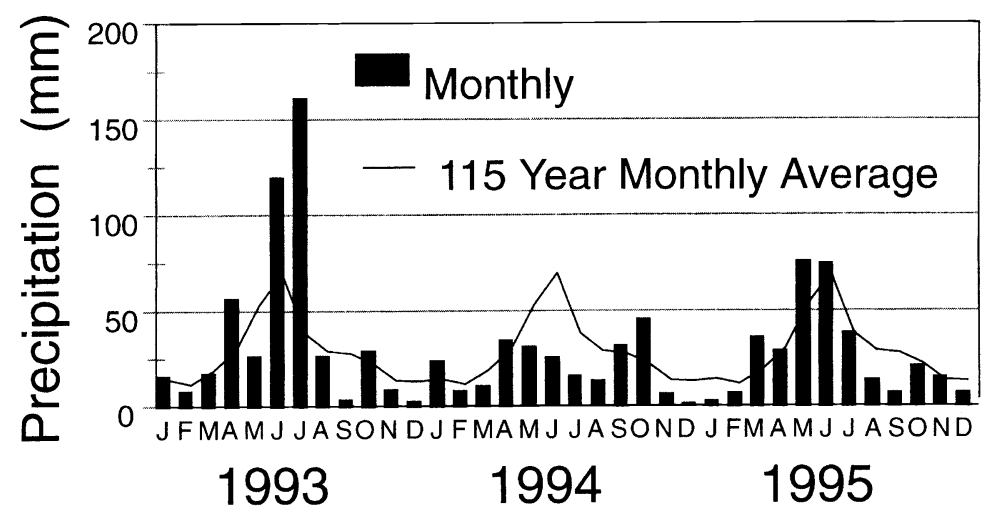

Fig. 1. Monthly precipitation (mm) from January 1993 through December 1995 and longterm monthly averages at Miles City, Mont. (NOAA 1996).

City, Mont. $\left(46^{\circ} 22^{\prime} \mathrm{N} 105^{\circ} 5^{\prime} \mathrm{W}\right)$. The study area was ungrazed by livestock from 1988 to the start of the study. Regional topography ranges from rolling hills to broken badlands with small intermittent streams that flow into large perennial rivers meandering through broad, low-gradient valleys. The regional natural vegetation is a grama-needlegrass-wheatgrass (Bouteloua-Stipa-Agropyron) mixed grass plant community (Kuchler 1964). Average annual precipitation is $341 \mathrm{~mm}$ and highly variable with about $60 \%$ received during the 150 day, mid-April to mid-September growing season (Fig. 1). Soil erosive precipitation events occur primarily from spring to summer as intense, short-duration thunderstorms. Other runoff events can occur with precipitation on frozen soil or during snow melt. Average daily temperatures range from a low of $-10^{\circ} \mathrm{C}$ in January to a high of $24^{\circ} \mathrm{C}$ in July with daily maximum temperatures occasionally exceeding $37^{\circ} \mathrm{C}$ during summer and daily minimums occasionally falling below $-40^{\circ} \mathrm{C}$ during winter.

\section{Study Lysimeters}

Twelve, non-weighing lysimeters, $5 \mathrm{~m}$ wide by $10 \mathrm{~m}$ long were installed in 1992 . Lysimeter walls were constructed by filling $12 \mathrm{~cm}$ wide by $2 \mathrm{~m}$ deep perimeter trenches with urethane foam insulation. Twenty $\mathrm{cm}$ wide wooden walls extending $15 \mathrm{~cm}$ above the soil were placed on top of the trenches and supported a metal $v$ notched cap to drain off any rainfall landing on the wall. At the lowest elevation point in each lysimeter, a concrete collection basin $2,100 \mathrm{~cm}^{2}$ in size was constructed and fitted with a drain and belowground piping to transport water and sediment to fiberglass collection tanks. The storage tanks were each fitted with 20-liter plastic canisters to collect and accurately measure small runoff volumes. For larger volumes, the canisters overflowed into the tank and the combined volumes used. Total tank capacity was calculated to be of sufficient size to measure a 100-year, 24 hour, runoff event (Hershfield 1961).

Vegetation within the lysimeters was a mixed grass dominance of western wheatgrass [Pascopyrum smithii Rydb. (Love)], a cool-season, perennial midgrass; blue grama [Bouteloua gracilis (H. B. K.) Lag. ex Griffiths], a warm-season, perennial shortgrass; and Japanese brome [Bromus japonicus Thunb. ex Murr.], a cool-season, annual midgrass (Heitschmidt et al. 1999). Soil was a Kobase silty clay loam (Fine, montmorillonitic, frigid, Aridic Ustochrept). Soil samples from the lysimeters had an average $\mathrm{pH}$ of $7.5,3.5 \%$ organic matter, and a cation exchange capacity of $26 \mathrm{meq} / 100 \mathrm{~g}$ of soil. Average soil particle size was 19,61 , and $20 \%$ sand, silt, and clay, respectively, with no rock fragments $(>2 \mathrm{~mm})$. Slope was southern and 4\%. Lysimeters were arranged perpendicularly along a $65-\mathrm{m}$ transect in 2 groups of 6 lysimeters with a 5-m space between groups.

\section{Treatments}

The drought treatment was imposed only during the second year (1994) of the 3-year study (1993-1995) from late May to mid-October. The drought treatment was intended to reduce growing season precipitation by $80 \%$, with precipitation early and late in the growing season producing runoff. A $12 \times 35-\mathrm{m}$ automated, metal-framed, rainout shelter was mounted on wheels and rails about $75 \mathrm{~cm}$ above the soil surface of 1 of the two, 6-lysimeter 
sets, hereafter referred to as the drought treatment lysimeters. Rails extended from the top edge of the lysimeters to $25 \mathrm{~m}$ below the bottom edge. Rails were located directly over lysimeter borders. It was equipped with a moisture sensitive conductance plate that, when wetted, activated a small electric motor and its associated drive system to move the shelter over the lysimeters.

Three grazing treatments, twice replicated, were imposed randomly on both nondrought and drought treatment lysimeters. Grazing treatments were: 1) graze both the year of (i.e., 1994) and the year after (i.e., 1995) imposed drought, hereafter referred to as the 94-95 grazed treatment; 2) graze during the year of drought (i.e., 1994) and rest the year after, hereafter referred to as the 94 grazed treatment; and 3) rest for all 3 years (i.e. 1993-95), hereafter referred to as the ungrazed treatment. The grazing treatments were applied by placing 6 ewes and their twin lambs in each lysimeter for 1 day in early June and early July, which represented before and during peak standing biomass for the growing season. Grazing continued until an estimated $50 \%$ of the standing biomass was removed to achieve a heavy grazing treatment. In $1994,40 \%$ of the standing plant biomass was removed during each grazing event and $50 \%$ in 1995 (Heitschmidt et al. 1999). Average year-end standing biomass was $1,000 \mathrm{~kg} \mathrm{ha}^{-1}$ in 1994 and $500 \mathrm{~kg} \mathrm{ha}^{-1}$ in 1995 which represented 35 and $30 \%$ of the ungrazed treatment, respectively.

\section{Sampling Procedures}

Soil chemical and physical properties were characterized by collecting eight, 4$\mathrm{cm}$ deep soil samples at stratified locations in each lysimeter in May 1993. Samples within each lysimeter were composited for analysis. Saturation extracts (Richards 1954) were used to determine $\mathrm{pH}$, electrical conductivity (EC), and soluble nutrient ion concentrations of $\mathrm{Ca}, \mathrm{Mg}, \mathrm{K}, \mathrm{Na}$, $\mathrm{NO}_{3}, \mathrm{NH}_{4}, \mathrm{PO}_{4}, \mathrm{Cl}, \mathrm{SO}_{4}$, and $\mathrm{HCO}_{3}$. The $\mathrm{PO}_{4}, \mathrm{Cl}, \mathrm{SO}_{4}, \mathrm{HCO}_{3}, \mathrm{NO}_{3}$, and $\mathrm{NH}_{4}$ concentrations were determined using Technicon AutoAnalyzer II $^{1}$ standard procedures and the $\mathrm{Ca}, \mathrm{Mg}, \mathrm{K}$, and $\mathrm{Na}$ concentrations with a Perkin-Elmer 5000' atomic absorption spectrophotometer. Triplicate subsamples were digested according to Technicon procedure No.

\footnotetext{
${ }^{1}$ Mention of trade names or proprietary products does not indicate endorsement by USDA, and does not imply its approval to the exclusion of other products that may also be suitable.
}

376-75W/B and analyzed for total $\mathrm{N}$ and $\mathrm{P}$ with the Technicon AutoAnalyzer II using method No. 329-74W/B (Technicon 1977). Soil texture was determined by the hydrometer method (Day 1965) and organic matter content was determined using the Walkley-Black procedure (Nelson and Sommers 1982). Cation exchange capacity was estimated using ammonium acetate extraction (Bower et al. 1952).

Storm rainfall was measured on site from 1 May to 31 October using plastic rain gauges. Runoff and sediment samples were collected from each lysimeter between 1 May and 31 October for every runoff event. In all instances, water and sediment were channeled into the collection system located inside the large storage tanks. Runoff volume was estimated by weighing collected runoff samples and converting weight to volume, ignoring the weight of the sediment. Total sediment yield was estimated for all events by allowing the sediment in collected runoff to settle over time before decanting, centrifuging, drying at $65^{\circ} \mathrm{C}$, and weighing. Following all 1994 and 1995 runoff events, a $250-\mathrm{ml}$ aliquot sub-sample was collected from the runoff/sediment sample, centrifuged to remove any suspended sediment, and analyzed for ions using the same procedures as the soluble ions extracted from the soil. This $250-\mathrm{ml}$ subsample was not collected in 1993 and no data is available for that year. The dried sediment was then analyzed for total $\mathrm{N}$ and $\mathrm{P}$ concentrations (sed- $\mathrm{N}$ and sed-P, respectively) using the same procedures and methods as the soil samples. Volume of runoff, soluble ion, sediment, and sed-N and sed-P concentrations were used to calculate mass transport for each event. Total annual runoff, sediment, and nutrient yield were estimated by summation of individual events for each lysimeter.

\section{Analysis}

The experimental design was a $2 \times 3$ factorial completely randomized by grazing treatment. Total annual data were statistically analyzed using within years analysis of variance models. Main effects were drought and grazing treatments. The error term for testing for drought effects was replication (i.e., lysimeter) within drought treatment. The model residual was used to test for the main effect of grazing treatment and the drought by grazing treatment interaction effect. Main effects of drought and grazing were either pooled or separated depending on significance of the interactions $(P \leq 0.05)$. The potential for non-homogeneity of the variances with the small number of lysimeters within treatments was compensated for by evaluating the data and determining that a log transformation was most appropriate. For treatments with zeros because of no runoff, small values (i.e., 0.01-0.00001) were added to all the data to permit the transformation. The value was chosen to distinguish the zero value from the next larger value in the data set for each variable. The LSD test was used to separate means for treatment effects $(\mathrm{P} \leq 0.05)$.

\section{Results and Discussion}

\section{Predrought (1993)}

Runoff and erosion are the major processes that transport nutrients and should be most affected by the drought and grazing treatments. Total precipitation during 1993 was $519 \mathrm{~mm}, 52 \%$ above the long-term average of $341 \mathrm{~mm}$ (Fig. 1). The abundance of April through September growing season precipitation was fortunate because it provided an opportunity to clearly identify any inherent, pretreatment differences between lysimeters before treatments were applied for runoff and sediment yield. The lysimeters were analyzed as if all treatments had been applied. There were no significant differences $(P \leq 0.05)$ among treatments for runoff or sediment yield (Table 1). The above normal precipitation produced the highest annual runoff and sediment yield values observed during the study. The trend toward more runoff and sediment yield on the non-drought lysimeters may have been related to vegetation composition differences among lysimeters reported by Heitschmidt et al. (1999). Average cool-season perennial grasses on the drought lysimeters was 572 vs. $1,237 \mathrm{~kg}$ $\mathrm{ha}^{-1}$ for the non-drought and 1,446 vs $1,094 \mathrm{~kg} \mathrm{ha}^{-1}$ for warm-season perennial grasses, respectively. Although vegetation type and amount can influence runoff and erosion (Warren et al. 1986a), its influence in our study was not large enough to produce significant differences, therefore, any future effects were considered to be related to the treatments and not the vegetation.

Analyses of soil revealed no significant differences among lysimeters in either soil texture, soil organic matter content, cation exchange capacity, total-N, total-P, or soluble nutrient ion concentrations other than chlorine (data not shown). Chlorine concentrations were significantly greater in the non-drought lysimeters than drought (6 vs $3 \mu \mathrm{g} \mathrm{g}^{-1}$ soil), but the values were so 
Table 1. Effect of drought and non-drought treatments on runoff, sediment yield, and nutrient transport from 1 May to 31 October for 1993-1995. No runoff occurred from drought lysimeters in 1994, the year drought was applied. Values are averages across grazing treatments.

\begin{tabular}{|c|c|c|c|c|c|}
\hline \multirow[t]{3}{*}{ Variable } & \multicolumn{5}{|c|}{ Year } \\
\hline & \multicolumn{2}{|c|}{1993} & \multirow{2}{*}{$\frac{1994^{1}}{\text { Non-Drought }}$} & \multicolumn{2}{|c|}{$1995^{2}$} \\
\hline & Non-Drought & Drought & & Non-Drought & Drought \\
\hline $\mathrm{Ca}$ & $-{ }^{3}$ & - & $\begin{array}{c}-\left(\mathrm{g} \mathrm{ha}^{-1}\right)- \\
10.0 \\
(2.9)^{4}\end{array}$ & $\begin{array}{l}11.8 \mathrm{a} \\
(5.3)\end{array}$ & $\begin{array}{c}27.0 \mathrm{a} \\
(9.9)\end{array}$ \\
\hline $\mathrm{Mg}$ & - & - & $\begin{array}{l}4.1 \\
(1.2)\end{array}$ & $\begin{array}{r}3.2 \mathrm{a} \\
(1.6)\end{array}$ & $\begin{array}{l}4.8 \mathrm{a} \\
(1.9)\end{array}$ \\
\hline K & - & - & $\begin{array}{c}6.4 \\
(1.7)\end{array}$ & $\begin{array}{l}7.5 \mathrm{a} \\
(3.8)\end{array}$ & $\begin{array}{l}11.4 \mathrm{a} \\
(4.8)\end{array}$ \\
\hline $\mathrm{Na}$ & - & - & $\begin{array}{c}2.4 \\
(0.4)\end{array}$ & $\begin{array}{l}5.8 \mathrm{a} \\
(2.4)\end{array}$ & $\begin{array}{l}4.7 \mathrm{a} \\
(1.7)\end{array}$ \\
\hline $\mathrm{NO}_{3}-\mathrm{N}$ & - & - & $\begin{array}{c}3.3 \\
(1.9)\end{array}$ & $\begin{array}{r}0.9 \mathrm{a} \\
(0.5)\end{array}$ & $\begin{array}{r}1.1 \mathrm{a} \\
(0.5)\end{array}$ \\
\hline $\mathrm{NH}_{3}$ & - & - & $\begin{array}{c}1.8 \\
(0.5)\end{array}$ & $\begin{array}{r}0.6 \mathrm{a} \\
(0.4)\end{array}$ & $\begin{array}{l}0.9 \mathrm{a} \\
(0.5)\end{array}$ \\
\hline $\mathrm{PO}_{4}-\mathrm{P}$ & - & - & $\begin{array}{c}0.24 \\
(0.06)\end{array}$ & $\begin{array}{l}0.23 \mathrm{a} \\
(0.15)\end{array}$ & $\begin{array}{l}0.46 \mathrm{a} \\
(0.26)\end{array}$ \\
\hline $\mathrm{Cl}$ & - & - & $\begin{array}{c}4.1 \\
(1.2)\end{array}$ & $\begin{array}{r}3.0 \mathrm{a} \\
(1.6)\end{array}$ & $\begin{array}{l}5.1 \mathrm{a} \\
(2.5)\end{array}$ \\
\hline $\mathrm{SO}_{4}$ & - & - & $\begin{array}{c}2.2 \\
(0.1)\end{array}$ & $\begin{array}{r}4.5 \mathrm{a} \\
(1.9)\end{array}$ & $\begin{array}{l}11.0 \mathrm{a} \\
(4.4)\end{array}$ \\
\hline $\mathrm{HCO}_{3}$ & - & - & $\begin{array}{l}20.9 \\
(4.9)\end{array}$ & $\begin{array}{l}30.1 \mathrm{a} \\
(12.8)\end{array}$ & $\begin{array}{l}46.1 \mathrm{a} \\
(16.8)\end{array}$ \\
\hline Sed-N ${ }^{5}$ & $\begin{array}{c}5.2 \\
(1.4)\end{array}$ & $\begin{array}{c}2.7 \\
(0.9)\end{array}$ & $\begin{array}{l}2.8 \\
(1.2)\end{array}$ & $\begin{array}{r}8.9 \\
(5.0)\end{array}$ & $\begin{array}{l}14.9 \\
(8.4)\end{array}$ \\
\hline Sed-P $\mathrm{P}^{5}$ & $\begin{array}{l}1.2 \\
(0.3)\end{array}$ & $\begin{array}{c}0.6 \\
(0.2)\end{array}$ & $\begin{array}{c}0.5 \\
(0.2)\end{array}$ & $\begin{array}{c}1.5 \\
(0.9)\end{array}$ & $\begin{array}{c}2.9 \\
(1.7)\end{array}$ \\
\hline Sediment $^{5}$ & $\begin{array}{l}19,403 \\
(5,086)\end{array}$ & $\begin{array}{c}9,689 \\
(3,519)\end{array}$ & $\begin{array}{c}664 \\
(278)\end{array}$ & $\begin{array}{c}2,548 \\
(1,539)\end{array}$ & $\begin{array}{c}5,889 \\
(3,643)\end{array}$ \\
\hline Runoff & $\begin{array}{c}2.6 \\
(0.6)\end{array}$ & $\begin{array}{c}0.9 \\
(0.2)\end{array}$ & $\begin{array}{c}0.10 \\
(0.03)\end{array}$ & $\begin{array}{r}0.22 \mathrm{a} \\
(0.11)\end{array}$ & $\begin{array}{r}0.33 \mathrm{a} \\
(0.15)\end{array}$ \\
\hline
\end{tabular}

All 1994 non-drought means significantly different from zero at $\mathrm{P} \leq 0.05$.

${ }^{2}$ Means from 1995 within rows with the same letter are not significantly different at $\mathrm{P} \leq 0.05$.

${ }^{3}$ Not determined.

${ }^{4}$ Values in parentheses are standard errors.

${ }^{5}$ Sed-N, Sed-P, and Sediment in 1995 had a two-way grazing by drought interaction $\mathrm{P} \leq 0.05$.

small, it was not possible to attribute any environmental significance. Although runoff water quality analyses were not done, the soil is the dominant source of nutrients for transport in runoff water and sediment. The minimal soil differences and the absence of significant runoff and sediment yield differences indicated that future significant differences would be due to treatment effects.

\section{Drought (1994)}

Annual precipitation during 1994 was $256 \mathrm{~mm}, 25 \%$ below normal, with below typical growing season precipitation (Fig. 1). Precipitation from May through October was $163 \mathrm{~mm}$ as compared to the long-term average of $271 \mathrm{~mm}$. This produced the situation where a drought treatment was imposed in what turned out to be a below normal precipitation year. Drought treatment precipitation from 1 May through 31 October was $23 \mathrm{~mm}$ with 0 precipitation from 15 June to 15 October which produced no runoff from the drought treatment. Similar severe droughts have occurred in recent history. For example, there was only $34 \mathrm{~mm}$ of precipitation that fell between 15 May and 15 September 1988.

Runoff, sediment yield, and nutrient transport were all significantly greater from the non-drought than the drought treatment lysimeters because all were greater than zero (Table 1). The absence of runoff from drought treatment lysimeters eliminated the opportunity to statistically examine the interaction effects of drought and grazing during 1994. There were no differences between grazed and ungrazed treatments relative to any measured variable. We suspect this was largely because the total amount of runoff and sediment production was very limited in this study regardless of treatment. The ungrazed treatments did have more runoff $(0.14$ vs $0.08 \mathrm{~mm})$ and the grazed treatment had more sediment yield (914 vs 163 $\mathrm{g} \mathrm{ha}^{-1}$ ). Our results should not be perceived as being in conflict with the gener- ally accepted conclusion that grazing generally increases both surface runoff and sediment production (Dadkhah and Gifford 1980, Thurow et al. 1988, Thurow 1991). The results should be viewed as reflecting the reality that grazing in an arid environment with limited high intensity precipitation events, produces limited runoff and sediment production, at least for the period of this study.

\section{Post-drought (1995)}

Total precipitation during 1995 was 284 $\mathrm{mm}$ with above average spring rainfall (Fig. 1). Analyses of the post-drought 1995 data indicated no significant drought effect. The 1994 drought treatment did increase the runoff, sediment, and nutrient yield from the drought lysimeters in 1995 when compared to the non-drought (Table 1). This was largely because of the carryover effect of reduced standing plant biomass from the drought treatment. Heitschmidt et al. (1999) reported the standing plant biomass during 1995 averaged 1,259 and $1,673 \mathrm{~kg} \mathrm{ha}^{-1}$ in drought and non-drought treatment lysimeters, respectively, as compared to averages of 1,735 and $2,084 \mathrm{~kg} \mathrm{ha}^{-1}$ during 1994. A larger impact of the 1994 imposed drought may have been observed in 1995, if 1994 had not been a below normal precipitation year. Carry-over of the drought treatment effects to the following year are in agreement with other studies that have shown post-drought vegetation recovery varies in part as a function of drought severity and grazing intensities, and as such, so do hydrological recovery rates (Thurow et al. 1988).

The 94 grazed and 94-95 grazed treatments had significantly more runoff, sediment, and nutrient yield in 1995 than the ungrazed treatment (Tables 2 and 3 ). Nutrient yields were greater from the 9495 grazed than 94 grazed treatments, but only significantly so for $\mathrm{NH}_{3}$ and $\mathrm{PO}_{4}-\mathrm{P}$. For sediment, sed-N, and sed-P yields, there were significant drought by grazing treatment interactions (Table 3 ). These interactions showed that sediment, sed-N, and sed-P yields were: 1) significantly less on the ungrazed treatment with no runoff from the ungrazed non-drought treatment; 2) significantly greater on the non-drought 94-95 grazed treatment than the nondrought 94 grazed treatment; and 3) similar on the drought 94-95 grazed and drought 94 grazed treatment. An increase in sediment yield with increasing grazing has been related to aboveground biomass (Thurow et al. 1986). The average aboveground standing biomass was $782 \mathrm{~kg} \mathrm{ha}^{-1}$ 
Table 2. Effect of drought and non-drought treatments on runoff, sediment yield, and nutrient transport from 1 May to 31 October 1995 . Lysimeters were either ungrazed, grazed only in 1994, or grazed both in 1994 and 1995 . Values are averages across drought and non-drought treatments.

\begin{tabular}{|c|c|c|c|}
\hline Variable & Ungrazed & 94 Grazed & 94-95 Grazed \\
\hline $\mathrm{Ca}$ & $\begin{array}{c}0.5 \mathrm{a}^{1} \\
(0.4)^{2}\end{array}$ & $\begin{array}{c}-\left(\mathrm{g} \mathrm{ha}^{-1}\right)-- \\
25.2 \mathrm{~b} \\
(10.3)\end{array}$ & $\begin{array}{l}32.5 b \\
(4.1)\end{array}$ \\
\hline $\mathrm{Mg}$ & $\begin{array}{l}0.1 \mathrm{a} \\
(0.04)\end{array}$ & $\begin{array}{l}4.8 \mathrm{~b} \\
(1.9)\end{array}$ & $\begin{array}{l}7.1 \mathrm{~b} \\
(1.2)\end{array}$ \\
\hline K & $\begin{array}{l}0.2 \mathrm{a} \\
(0.2)\end{array}$ & $\begin{array}{l}10.1 \mathrm{~b} \\
(3.6)\end{array}$ & $\begin{array}{l}17.8 \mathrm{~b} \\
(4.1)\end{array}$ \\
\hline $\mathrm{Na}$ & $\begin{array}{r}0.2 \mathrm{a} \\
(0.2)\end{array}$ & $\begin{array}{l}5.9 \mathrm{~b} \\
(1.4)\end{array}$ & $\begin{array}{l}9.6 \mathrm{~b} \\
(1.6)\end{array}$ \\
\hline $\mathrm{NO}_{3}-\mathrm{N}$ & $\begin{array}{l}0.01 \mathrm{a} \\
(0.004)\end{array}$ & $\begin{array}{c}0.96 \mathrm{~b} \\
(0.20)\end{array}$ & $\begin{array}{r}2.08 \mathrm{~b} \\
(0.59)\end{array}$ \\
\hline $\mathrm{NH}_{3}$ & $\begin{array}{l}0.01 \mathrm{a} \\
(0.004)\end{array}$ & $\begin{array}{c}0.47 \mathrm{~b} \\
(0.33)\end{array}$ & $\begin{array}{l}1.75 \mathrm{c} \\
(0.52)\end{array}$ \\
\hline $\mathrm{PO}_{4}-\mathrm{P}$ & $\begin{array}{r}0.001 \mathrm{a} \\
(0.001)\end{array}$ & $\begin{array}{r}0.31 \mathrm{~b} \\
(0.17)\end{array}$ & $\begin{array}{r}0.73 \mathrm{c} \\
(0.36)\end{array}$ \\
\hline $\mathrm{Cl}$ & $\begin{array}{l}0.1 \mathrm{a} \\
(0.04)\end{array}$ & $\begin{array}{l}4.5 \mathrm{~b} \\
(2.0)\end{array}$ & $\begin{array}{l}7.6 \mathrm{~b} \\
(2.2)\end{array}$ \\
\hline $\mathrm{SO}_{4}$ & $\begin{array}{l}0.2 \mathrm{a} \\
(0.2)\end{array}$ & $\begin{array}{c}8.5 \mathrm{~b} \\
(2.7)\end{array}$ & $\begin{array}{l}14.6 \mathrm{~b} \\
(3.8)\end{array}$ \\
\hline $\mathrm{HCO}_{3}$ & $\begin{array}{l}1.3 \mathrm{a} \\
(1.1)\end{array}$ & $\begin{array}{l}46.9 \mathrm{~b} \\
(16.0)\end{array}$ & $\begin{array}{l}66.1 \mathrm{~b} \\
(6.0)\end{array}$ \\
\hline Sed-N ${ }^{3}$ & $\begin{array}{c}0.2 \\
(0.2)\end{array}$ & $\begin{array}{l}12.9 \\
(7.9)\end{array}$ & $\begin{array}{l}22.6 \\
(6.8)\end{array}$ \\
\hline Sed-P ${ }^{3}$ & $\begin{array}{c}0.03 \\
(0.03)\end{array}$ & $\begin{array}{c}2.19 \\
(1.36)\end{array}$ & $\begin{array}{l}4.35 \\
(1.54)\end{array}$ \\
\hline Sediment ${ }^{3}$ & $\begin{array}{l}31 \\
(25)\end{array}$ & $\begin{array}{c}3,972 \\
(2,650)\end{array}$ & $\begin{array}{c}8,652 \\
(3,553)\end{array}$ \\
\hline Runoff & $\begin{array}{c}0.007 \mathrm{a} \\
(0.006)\end{array}$ & $\begin{array}{c}0.359 \mathrm{~b} \\
(0.162)\end{array}$ & $\begin{array}{r}0.470 \mathrm{~b} \\
(0.098)\end{array}$ \\
\hline
\end{tabular}

${ }^{1}$ Values within rows with the same letter are not significantly different at $\mathrm{P} \leq 0.05$

${ }^{2}$ Values in parentheses are standard errors.

${ }^{3}$ Sed-N, Sed-P, and Sediment had a two-way grazing by drought interaction $\mathrm{P} \leq 0.05$.

for the 94-95 grazed, $1,422 \mathrm{~kg} \mathrm{ha}^{-1}$ for the 94 grazed, and $2,196 \mathrm{~kg} \mathrm{ha}^{-1}$ for the ungrazed treatments (Heitschmidt et al. 1999). The sediment yield and standing biomass data agrees with other studies that have shown good correlations between them (Thurow et al. 1986, Warren et al. 1986a). Although not large, the combination of drought and gazing did produce a trend toward increased runoff and sediment yield (Tables 1, 2, and 3).

The drought and grazing treatment impacts were small and the potential increase in water yield from the treatments was small (Tables 1 and 2). This small impact was surprising in light of other studies showing dramatically accelerated runoff and erosion (e.g., see reviews by Blackburn 1984 and Thurow 1991). Most of these studies were conducted in regions experiencing much greater intensity of rainfall and/or results derived from simulated, high intensity rainfall events. The conditions of this study were much different in that annual precipitation was low and individual rainfall events were generally small. For example, there were 104 precipitation events during 1993, 1994, and 1995 between 1 May and 31 October. Of these events, 79 were $<10 \mathrm{~mm}$ in magnitude and only 6 were $>20 \mathrm{~mm}$ with the largest being $61.2 \mathrm{~mm}$ (7 Jun 1993).
Runoff from the lysimeters averaged about $20 \mathrm{~mm}$ during this event. The 7 June event was long in duration with a maximum rainfall rate of $6.6 \mathrm{~mm}$ per hour and represented a 1 in 10 year, 12-hour rainfall event (Hershfield 1961). These data emphasize that erosive rainfall events are rare in this region and that the yearly variability in precipitation was a larger factor in runoff than any of the treatments, as shown by 1993, an above average year, and 1994 a below normal year (Fig. 1, Table 1). As a result, runoff from this range site was low and quality was generally better than EPA (1976) standards. The sediment and nutrient levels realized in this study are in close agreement with those of Owens et al. (1983) and Barros et al. (1995), and specifically by Neff (1982) for an analogous Montana rangeland soil.

\section{Summary and Conclusions}

The absence of runoff from the drought treatment lysimeters during the 1994 below normal precipitation year prevented a direct assessment of drought and grazing interactions. However, 1 year after the drought treatment (1995), the hypothesized substantial increase in runoff, sediment, and nutrient transport from the combined effects of drought and grazing did not materialize, only an increasing trend for runoff and sediment yield. After the drought treatment, runoff and sediment yields increased and water quality was reduced. Grazing produced significant increases in runoff and sediment yield and
Table 3. Effects of drought and grazing on sediment nitrogen (Sed-N), sediment phosphorus (Sed-P), and total sediment transport from 1 May to 31 October 1995. Lysimeters were either ungrazed, grazed only in 1994, or grazed both in 1994 and 1995.

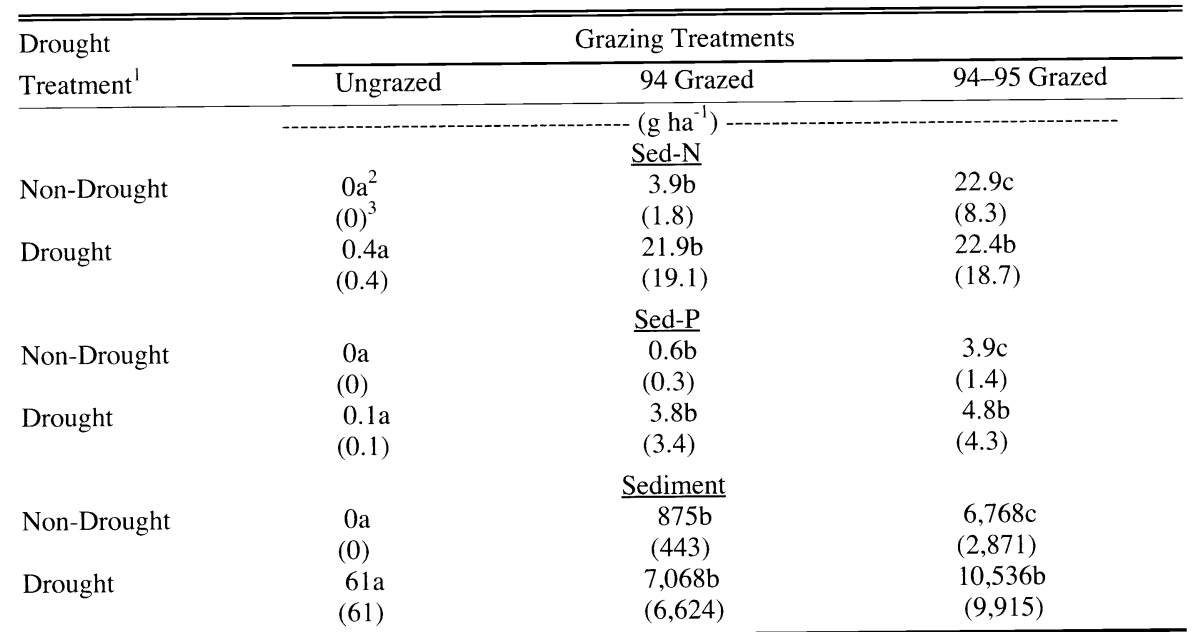

The two-way grazing by drought interaction was significant at $\mathrm{P} \leq 0.05$.

${ }^{2}$ Values within rows with the same letter are not significantly different at $P \leq 0.05$.

${ }^{3}$ Values in parentheses are standard errors. 
decreases in water quality compared to no grazing. These increases were concluded to be minimal under the drought and grazing conditions evaluated in this study when compared to the yearly natural variability at the site.

\section{Literature Cited}

Barros, M.C., M.J.M. Mendo, and F.C.R. Negrao. 1995. Surface water quality in Portugal during a drought period. Sci. Total Environ. 171:69-76.

Blackburn, W.H. 1984. Impacts of grazing intensity and specialized grazing systems of watershed characteristics and responses, $p$. 927-983. In: Developing Strategies for Rangeland Management. Nat. Res. Counc., Nat. Acad. Sci., Westview Press, Boulder, Colo.

Bower, C.A., R.F. Reitemeirer, and M. Fireman. 1952. Exchangeable cation analysis of saline and alkali soils. Soil Sci. 73:251-261.

Dadkhah, M. and G.F. Gifford. 1980. Influence of vegetation, rock cover, and trampling on infiltration rates and sediment production. Water Resour. Bull. 16:979-986.

Day, P.R. 1965. Particle fractionation and particle-size analysis. In: C.A. Black (ed.), Methods of soil analysis. Part I. Agron. 9:545-576.

EPA. 1976. Quality criteria for water. U.S. Environ. Protection Agency, Washington, D.C.

Gifford, G.F. and R.R. Hawkins. 1978. Hydrologic impact of grazing on infiltration: A critical review. Water Resour. Res. 14:305-313.

Hanson, C.B., H.G. Heinemann, A.R. Kuhlman, and J.W. Neuberger. 1970. Grazing effects on runoff and vegetation on western South Dakota rangeland. J. Range Manage. 23:418-420

Heitschmidt, R.K., M.R. Haferkamp, M.G. Karl, and A.L. Hild. 1999. Drought and grazing: I. Effects on quantity of forage production. J. Range Manage. 52:440-446.
Hershfield, D.M.. 1961. Rainfall frequency atlas of the United States for duration from 30 minutes to 24 hours and return periods for 1 to 100 years. Tech. Paper No. 40 U.S. Dept. of Commerce Weather Bureau. Washington D.C.

Hofmann, L., R.E. Ries, and J.E. Gilley. 1983. Relationship of runoff and soil loss to ground cover of native and reclaimed grazing land. Agron. J. 75:599-602.

Jawson, M.D., L.F. Elliott, K.E. Saxton, and D.H. Fortier. 1982. The effect of cattle grazing on nutrient losses in a pacific Northwest setting. J. Environ. Qual. 11:628-631.

Kothmann, M.M. 1974. A glossary of terms used in range management. Soc. Range Manage., Denver, Colo.

Kuchler, A.W. 1964. Potential natural vegetation of the coterminous United States. Amer. Geogr. Soc. Spec. Pub. 36, New York, N.Y.

McGinty, W.A, R.E. Smeins, and L.B. Merrill. 1979. Influence of soil, vegetation, and grazing management on infiltration rate and sediment production of Edwards Plateau rangeland. J. Range Manage. 32:33-37.

National Oceanic and Atmospheric Administration. 1996. Climatological data Montana annual summary. National Climatic Data Center, Asheville, N.C.

Neff, E.L. 1982. Chemical quality and sediment content of runoff water from southeastern Montana rangeland. J. Range Manage. 35:130-132.

Nelson, D.A. and L.P. Sommers. 1982. Total carbon, organic carbon, and organic matter. In: A.L. Page et al. (eds.), Methods of soil analysis, Part II, 2nd ed. Agron. 9:539-579.

Owens, L.B., W.M. Edwards, and R.W. Van Kwuren. 1983. Surface runoff water quality comparisons between unimproved pasture and woodland. J. Environ. Qual. 12:518-522.

Richards, L.A. 1954. Diagnosis and improvement of saline and alkali soils. Agr. Handb.. 60. USDA-ARS, Washington D.C.

Robbins, J.W.D. 1979. Impact of unconfined livestock activities on water quality. Trans. ASAE. 22:1317-1323.
Schepers, J.S. and D.D. Francis. 1982. Chemical water quality of runoff from grazing land in Nebraska: I. Influence of grazing livestock. J. Environ. Qual. 11:351-354.

Schepers, J.S., B.L. Hackes, and D.D. Francis. 1982. Chemical water quality of runoff from grazing land in Nebraska: II. Contributing factor. J. Environ. Qual. 11:355-359.

Technicon Industrial Systems. 1977. Industrial method No. 376-75W/B and 32974W/B. Tarrytown, N.Y.

Thurow, T.L. 1991. Hydrology and erosion. p. 141-159. In: R.K. Heitschmidt and J.W. Stuth (eds.), Grazing management: An ecological perspective. Timber Press, Portland, Ore.

Thurow, T.L. and C.A. Taylor, Jr. 1999. Viewpoint: The role of drought in range management. J. Range Manage. 52:413-419.

Thurow, T.L., W.H. Blackburn, and C.A. Taylor, Jr. 1986. Hydrologic characteristics of vegetation types as affected by livestock grazing systems, Edwards Plateau, Texas. J. Range Manage. 39:505-509.

Thurow, T.L., W.H. Blackburn, and C.A. Taylor, Jr. 1988. Infiltration and interrill erosion responses to selected livestock grazing strategies, Edwards Plateau, Texas. J. Range Manage. 41:296-302.

Warren, S.D., W.H. Blackburn, and C.A. Taylor, Jr. 1986a. Effects of season and stage of rotation cycle on hydrologic condition of rangeland under intensive rotation grazing. J. Range Manage. 39:486-491.

Warren, S.D., M.B. Nevill, W.H. Blackburn, and N.E. Garza. 1986b. Soil response to trampling under intensive rotation grazing. Soil Sci. Soc. Amer. 50:1336-1341.

White, C.S. and S.R. Loftin. 2000. Response of 2 semiarid grasslands to cool-season prescribed fire. J Range Manage. 53:52-61.

Wood, M.K. and W.H. Blackburn. 1981. Sediment production as influenced by livestock grazing in the Texas rolling plains. J. Range Manage. 34:228-231. 